\title{
Jaw functional orthopedics is a therapeutic alternative for class III malocclusion: a case report
}

\author{
Maria Rita Xavier Sancho Rios ${ }^{1}$, Andrea Alves De Carvalho², Adrião Silveira Martins ${ }^{3}$, \\ Anne Souza Nery ${ }^{4}$, Maria Amélia Drummond 5 \\ Brazilian Dental Association, Salvador, Bahia, Brazil \\ ${ }^{1}$ Corresponding author \\ E-mail: ${ }^{1}$ mrsancho560@gmail.com, ${ }^{2}$ deacarvalho.40@gmail.com, ${ }^{3}$ adriaosilveiramartins@gmail.com, \\ ${ }^{4}$ annesouzanery@gmail.com, ${ }^{5}$ meldrummond01@gmail.com
}

Received 14 May 2021; received in revised form 29 June 2021; accepted 8 July 2021 DOI https://doi.org/10.21595/jfocg.2021.22059

Check for updates

Copyright (C) 2021 Maria Rita Xavier Sancho Rios, et al. This is an open access article distributed under the Creative Commons Attribution License, which permits unrestricted use, distribution, and reproduction in any medium, provided the original work is properly cited.

\begin{abstract}
Several dentistry specialists have discussed the effectiveness of the treatment of Class III malocclusion in the primary dentition and the beginning of mixed dentition. Jaw functional orthopedics offers therapeutic resources to control this malocclusion at a timely age since it does not require dental anchorage. Children with Class III malocclusion have difficulty in chewing, phonation, and appearance is negatively affected. The unraveling of the bite, as soon as possible, is essential to offer the facial maxillary complex the proper function during the child's development. The cases presented here demonstrate the immediate effect of these therapeutic resources. The patients (age ranging from three to five years old, three girls and one boy) sought orthodontic care because of anterior crossbite. They were treated at an opportune age through functional orthopedic devices to draw attention to these therapeutic resources and their immediate results. Additionally, through a search in the PubMed (MEDLINE) database, in April 2021, using the terms "class III malocclusion" and "early treatment" and using the time limit filter of the last ten years, in English, 28 articles from reviews and clinical trials were found. Of which, by reading the abstracts, 20 were selected. Classic books and articles on Jaw Functional Orthopedics were also consulted. This brief review aims to theoretically reference this article in which four clinical cases were described.
\end{abstract}

Keywords: jaw functional orthopedics, malocclusion class iii, early orthodontic treatment, case report.

\section{Introduction}

Mesiocclusion is characterized by the crossing of anterior teeth and has several definitions in the literature. In addition, it is characterized by an anterior-posterior dental discrepancy, which may or may not be accompanied by skeletal changes, such as posterior-anterior dental and facial discrepancies and sometimes with associated genetic components which may also present transversal and vertical problems, making it one of the most challenging malocclusions to treat, to control and to provide stability [1]-[4].

The prevalence of class III malocclusion ranges from 0 to $26.7 \%$, being more prevalent in Southeast Asia and less prevalent in India. In Brazil, there is an average prevalence of $3 \%$ [1], [5].

In 2013, Wilma Simões classified mesioclusions into 11 subtypes: genetic, structural, functional, transitional, with an extreme overbite, hyperdivergent, mutilated complex, with posterior disc displacement, dysplastic, with asymmetric mandibular prognathism, and mandibular hyperplasia [6].

In mixed dentition, there are effectively three types of Class III malocclusions:

1. Dental: inclination or incorrect position of the maxilla or lower incisors.

2. Pseudo: anterior positioning of the mandible due to premature dental contacts that deflect the mandible anteriorly to allow the patient to achieve intercuspation. 
3. Skeletal: true skeletal discrepancies either in the maxilla or in the mandible [1].

The American Academy of Pediatric Dentistry recommends that in primary dentition, crossbites should be diagnosed, and as they are unlikely to be self-correcting, they should be treated as early as possible to facilitate normal occlusal relationships. In mixed dentition, it recommends, among others, the treatment of crossbites taking advantage of the child's growth and should aim to prevent adverse effects related to the child's skeletal relationship. It recommends that habits of non-nutritive sucking, bruxism, atypical swallowing, abnormal tongue position, self-injurious/self-mutilating behavior, and obstructive sleep apnea should be observed in assessments of the development of occlusion [7]. Despite little evidence regarding skeletal factors and/or occlusal with temporomandibular disorders, there are some critical associations in some studies related to skeletal anterior open bite, steep joint eminence, overjet greater than six to seven millimeters, Class III malocclusion, Class II skeletal profile, unilateral posterior crossbite, and posterior crossbite [8].

However, several factors must be considered before starting the treatment of mesiocclusion, as Turpin has already described since 1953 (Table 1) [9].

Table 1. Factors described by Turpin that must be considered before addressing mesiocclusion

\begin{tabular}{|c|c|}
\hline Positive factors & Negative factors \\
\hline Convergent facial type & Divergent facial type \\
\hline Anteroposterior functional shift & No anteroposterior shift \\
\hline Symmetrical condyle growth & Asymmetrical growth of condyle \\
\hline Young subject with remaining growth & Growth completed \\
\hline Mild skeletal disharmony & Several skeletal disharmonies \\
\hline Good cooperation expected & Poor cooperation expected \\
\hline No familial prognathism & Familial pattern established \\
\hline Good facial aesthetics & Poor facial aesthetic \\
\hline
\end{tabular}

Therefore, the differential diagnosis of mesiocclusion is fundamental to determine what type of treatment we should choose.

In jaw functional orthopedics, it is mandatory to unravel the anterior bite, regardless of the type of mesiocclusion the patient may present. First of all, this unraveling is necessary to harmonize the bone bases in a more favorable position for the patient's other needs, such as swallowing, phonation, chewing, and aesthetics [10]-[14].

By interpreting and applying the Prevention Levels in Occlusopathies, we know that in the Secondary Lower Level of the first Category applied to primary dentition, devices are placed only in certain patients with crossbite - anterior crossbites and in those with severe dysplasias [15].

It has been discussed in the literature about the effectiveness of treating Class III malocclusion at an appropriate age, always seeking stability, but most of these authors have studied the use of a face mask, few have used functional orthopedic devices in their studies, as shown in the table below (Table 2). This table is associated with a non-systematic search performed in PubMed using the following terms: "early treatment" AND "Class III malocclusion".

In this article, four clinical cases will be described, with different functional approaches, with the objective of drawing attention to these therapeutic resources and their immediate results, modifying the mandibular posture and consequently, the dental skeletics and mandibular relation, enabling the maxilla and all the facial complex to receive adequate stimuli enabling better conditions for harmonious growth [10]-[14], [16].

In all the cases described, there is a new touch between the incisors, a new posture, and mandibular dynamics, respecting the principles of Jaw Functional Orthopedics. 
Table 2. Identification information of the literature review performed

\begin{tabular}{|c|c|c|c|c|c|}
\hline 2018 & $\begin{array}{l}\text { Alhammadi } \\
\text { et al. }\end{array}$ & $\begin{array}{l}\text { Global distribution of } \\
\text { malocclusion traits: A } \\
\text { systematic review }\end{array}$ & $\begin{array}{l}\text { Saudi } \\
\text { Arabia }\end{array}$ & $\begin{array}{l}\text { Systematic } \\
\text { review }\end{array}$ & $\begin{array}{c}\text { Dental Press J } \\
\text { Orthod. 2018 Nov- } \\
\text { Dec;23(6):40.e1-10 }\end{array}$ \\
\hline 2015 & Bock et al. & $\begin{array}{l}\text { Removable plate } \\
\text { treatment of anterior } \\
\text { forced crossbite. } \\
\text { Effectiveness, efficiency, } \\
\text { and potential outcome } \\
\text { predictors }\end{array}$ & Germany & Clinical study & $\begin{array}{l}\text { J Orofac Orthop } \\
\text { Vol. 76, p. 1-11, } \\
2015\end{array}$ \\
\hline 2011 & Borrie et al. & $\begin{array}{l}\text { Early correction of } \\
\text { anterior crossbites: a } \\
\text { systematic review }\end{array}$ & $\begin{array}{l}\text { United } \\
\text { Kingdom }\end{array}$ & $\begin{array}{l}\text { Systematic } \\
\text { review }\end{array}$ & $\begin{array}{c}\text { Journal of } \\
\text { Orthodontics, } \\
\text { Vol. 38, 2011, 175- } \\
184\end{array}$ \\
\hline 2020 & $\begin{array}{l}\text { Fabozzia et } \\
\quad \text { al. }\end{array}$ & $\begin{array}{l}\text { Comparison of two } \\
\text { protocols for early } \\
\text { treatment of dentoskeletal } \\
\text { Class III malocclusion: } \\
\text { Modified SEC III versus } \\
\text { RME/FM }\end{array}$ & Italy & Clinical study & $\begin{array}{l}\text { Orthod Craniofac } \\
\text { Res } 2020 \text { Nov } 11\end{array}$ \\
\hline 2019 & Khalaf et al. & $\begin{array}{l}\text { Removable appliances to } \\
\text { correct anterior crossbites } \\
\text { in the mixed dentition: a } \\
\text { systematic review }\end{array}$ & $\begin{array}{l}\text { United } \\
\text { Arab } \\
\text { Emirates }\end{array}$ & $\begin{array}{l}\text { Systematic } \\
\text { review }\end{array}$ & $\begin{array}{c}\text { Acta Odontol Scand } \\
\text { 2020 Mar; } \\
\text { 78(2):118-125 }\end{array}$ \\
\hline 2014 & Khan et al. & $\begin{array}{c}\text { Early Treatment of Class } \\
\text { III Malocclusion: A Boon } \\
\text { or a Burden? }\end{array}$ & India & Review & $\begin{array}{l}\text { Int J Clin Pediatr } \\
\text { Dent 2014; } \\
\text { 7(2):130-136. }\end{array}$ \\
\hline 2016 & $\begin{array}{l}\text { Mandall et } \\
\text { al. }\end{array}$ & $\begin{array}{l}\text { Early class III protraction } \\
\text { facemask treatment } \\
\text { reduces the need for } \\
\text { orthognathic surgery: a } \\
\text { multi-centre, two-arm } \\
\text { parallel randomized, } \\
\text { controlled trial }\end{array}$ & $\begin{array}{l}\text { United } \\
\text { Kingdom }\end{array}$ & Controlled trial & $\begin{array}{c}\text { Journal of } \\
\text { Orthodontics, } \\
\text { Vol. } 43,2016,164- \\
175\end{array}$ \\
\hline 2018 & $\begin{array}{l}\text { Menendez- } \\
\text { Díaz et al. }\end{array}$ & $\begin{array}{l}\text { Early treatment of Class } \\
\text { III malocclusion with } \\
\text { facemask therapy }\end{array}$ & Spain & $\begin{array}{l}\text { Retrospective } \\
\text { study }\end{array}$ & $\begin{array}{l}\text { Clin Exp Dent Res. } \\
\text { 2018; } 1-5\end{array}$ \\
\hline 2019 & $\begin{array}{l}\text { Minase et } \\
\text { al. }\end{array}$ & $\begin{array}{l}\text { Effectiveness of reverse } \\
\text { twin block with lip pads- } \\
\text { RME and face mask with } \\
\text { RME in the early } \\
\text { treatment of class III } \\
\text { malocclusion }\end{array}$ & India & $\begin{array}{l}\text { Random } \\
\text { clinical trial }\end{array}$ & $\begin{array}{c}\text { Progress in } \\
\text { Orthodontics (2019) } \\
20: 14\end{array}$ \\
\hline 2005 & Ngan & $\begin{array}{l}\text { Early Timely Treatment } \\
\text { of Class III Malocclusion }\end{array}$ & $\begin{array}{l}\text { Unites } \\
\text { States of } \\
\text { America }\end{array}$ & $\begin{array}{l}\text { Random } \\
\text { clinical trial }\end{array}$ & $\begin{array}{c}\text { Semin Orthod } \\
11: 140-1452005\end{array}$ \\
\hline
\end{tabular}




\begin{tabular}{|c|c|c|c|c|c|}
\hline 2015 & Ngan et al. & $\begin{array}{l}\text { Evolution of Class III } \\
\text { treatment in orthodontics }\end{array}$ & $\begin{array}{l}\text { United } \\
\text { States of } \\
\text { America }\end{array}$ & Review & $\begin{array}{c}\text { Am J Orthod } \\
\text { Dentofacial Orthop } \\
\text { 2015; 148:22-36 }\end{array}$ \\
\hline 2015 & Perillo et al. & $\begin{array}{l}\text { Comparisons of two } \\
\text { protocols for the early } \\
\text { treatment of Class III } \\
\text { dentoskeletal disharmony }\end{array}$ & Italy & Clinical study & $\begin{array}{c}\text { European Journal of } \\
\text { Orthodontics, 2015, } \\
1-6\end{array}$ \\
\hline 2020 & $\begin{array}{l}\text { Sarangal et } \\
\text { al. }\end{array}$ & $\begin{array}{l}\text { Treatment Modalities for } \\
\text { Early Management of } \\
\text { Class III Skeletal } \\
\text { Malocclusion: A Case } \\
\text { Series }\end{array}$ & India & Case Series & $\begin{array}{l}\text { Contemp Clin Dent. } \\
2020 \text { Jan-Mar; } \\
\text { 11(1): 91-96. }\end{array}$ \\
\hline 2012 & $\begin{array}{l}\text { Seehraa et } \\
\text { al. }\end{array}$ & $\begin{array}{l}\text { A comparison of two } \\
\text { different techniques for } \\
\text { early correction of Class } \\
\text { III malocclusion }\end{array}$ & $\begin{array}{l}\text { United } \\
\text { Kingdom }\end{array}$ & $\begin{array}{l}\text { Retrospective } \\
\text { study }\end{array}$ & $\begin{array}{l}\text { Angle Orthod. } 2012 \\
\text { Jan; 82(1):96-101 }\end{array}$ \\
\hline 2017 & Wendl et al. & $\begin{array}{c}\text { Retrospective } 25 \text {-year } \\
\text { follow-up of treatment } \\
\text { outcomes in Angle Class } \\
\text { III patients }\end{array}$ & Austria & $\begin{array}{l}\text { Retrospective } \\
\text { study }\end{array}$ & $\begin{array}{l}\text { J Orofac Orthop } \\
\text { (2017) 78:129-136 }\end{array}$ \\
\hline 2018 & $\begin{array}{l}\text { Willmann et } \\
\text { al. }\end{array}$ & $\begin{array}{l}\text { Early Class III treatment } \\
\text { with Hybrid-Hyrax- } \\
\text { Facemask in comparison } \\
\text { to HybridHyrax } \\
\text { Mentoplate - skeletal and } \\
\text { dental outcomes }\end{array}$ & Germany & $\begin{array}{l}\text { Retrospective } \\
\text { study }\end{array}$ & $\begin{array}{c}\text { Progress in } \\
\text { Orthodontics (2018) } \\
19: 42\end{array}$ \\
\hline 2017 & Woon et al. & $\begin{array}{l}\text { Early orthodontic } \\
\text { treatment for Class III } \\
\text { malocclusion: A } \\
\text { systematic review and } \\
\text { meta-analysis }\end{array}$ & $\begin{array}{l}\text { United } \\
\text { Kingdom }\end{array}$ & $\begin{array}{l}\text { Systematic } \\
\text { review and } \\
\text { meta-analysis }\end{array}$ & $\begin{array}{c}\text { Am J Orthod } \\
\text { Dentofacial Orthop } \\
\text { 2017; 151:28-52 }\end{array}$ \\
\hline
\end{tabular}

\section{Case presentation}

\subsection{Case 1}

MLB, in 2005, five years old, female, mixed-race Brazilian ("parda”).

Chief complaint: Anterior crossbite.

History of the current disease: No reports of complications during childbirth, development, and sleep. Absence of harmful habits.

Family history: Mother has the same Class III malocclusion.

At the initial examination, she reported dissatisfaction with her teeth; On initial clinical assessment, she presented a mandible/maxillary discrepancy, the beginning of eruption of first molars, and permanent lower central incisors.

The functional examination showed a simple broken compound protrusive movement. Bilateral chewing, phonation, and swallowing without changes. Mixed plan occlusal dentition. Complementary exams included panoramic radiography, profile teleradiograph, extra-oral photos of the face: frontal and right and left profile, and smile; intra-oral: frontal and lateral occlusion.

Upon lateral X-ray examination, the dental crossing of the primary incisors and 
maxillomandibular disproportions are observed.

Note the deficiency of the jaw in the photos in the lateral norm.

Therapeutics: Functional orthopedic device type SN3 with progeny arch, used for one year.

As its primary function, the chosen device has the mandibular rotation that induces a convenient lingual posture.
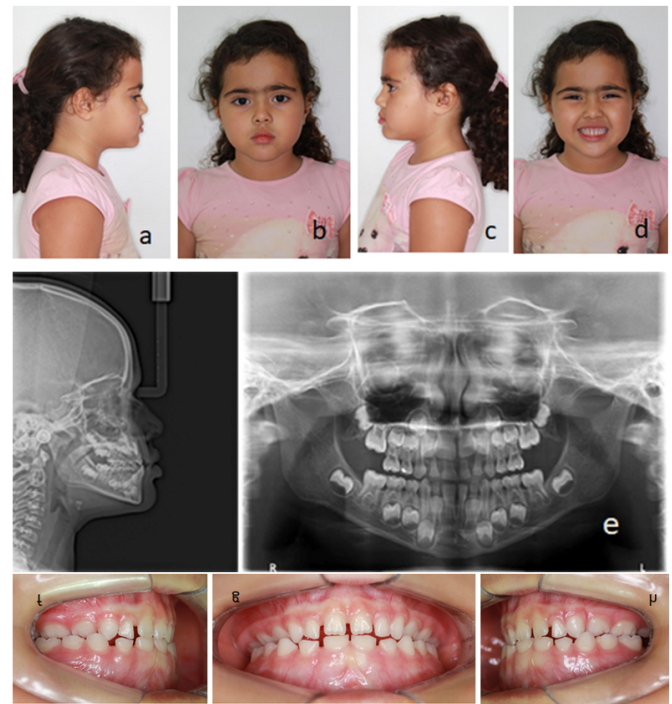

Fig. 1. Patient's registries in 2005. Face photographs: a) right profile; b) frontal; c) left profile;

d) smile; e) panoramic radiography and teleradiograph; f) intraoral - right profile;

g) intraoral - occlusion; and h) intraoral - left profile
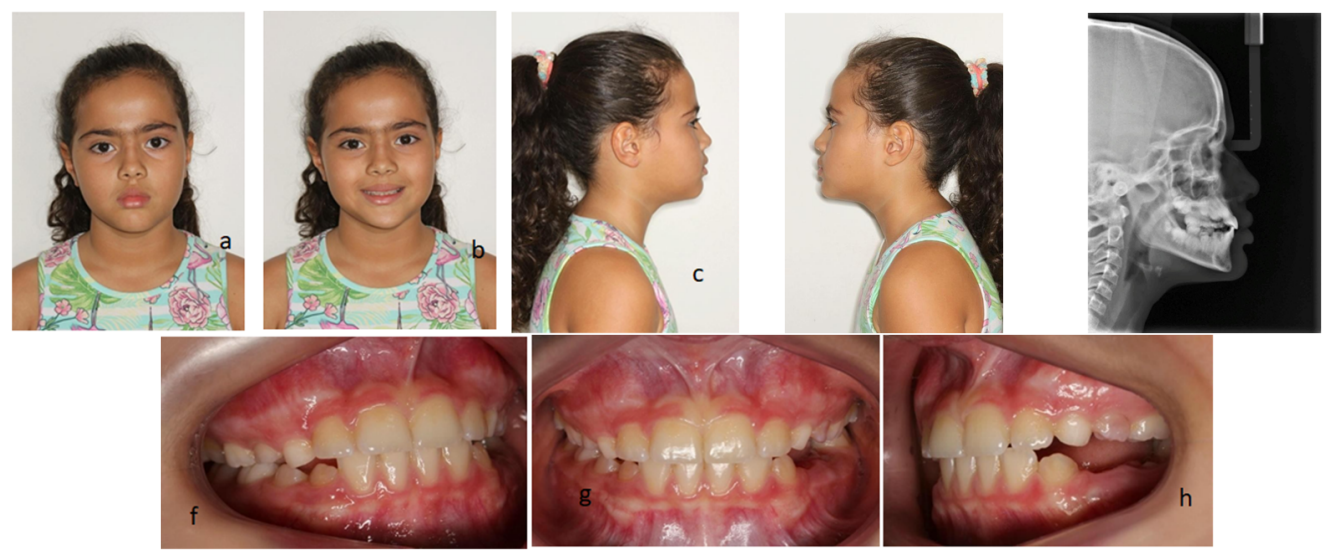

Fig. 2. Patient's registries in 2016. Pictures were taken after the use of SN3 with Eschler's arch. Face photographs: a) frontal profile; b) frontal profile - smile; c) right profile; d) left profile; e) teleradiograph; f) intraoral - right profile; g) intraoral - occlusion; and h) intraoral - left profile

After one year of treatment, the clinical examination shows the unraveling of the anterior bite, a better mandibular-maxillary relationship, and a better-positioned maxilla.

\subsection{Case 2}

Patient: PDM, five years old, female, mixed-race Brazilian ("parda"). Clinical examination highlighted the complaint of "different dentition", irregular sleep, daytime sleepiness, ashamed of going to school. 
History of the current disease: Healthy child, without any systemic complaints.

Family history: Without cases of mesiocclusion. Other types of malocclusion were not reported.

On clinical examination, mesiocclusion, without bone base discrepancy and harmonic profile. Facial image analyses evidenced a tendency to vertical growth with an open gonial angle. No numerical and cephalometric data is showed because, at that age, no validated parameters are yet established.

Proposed Therapy: In assessing priorities, the primary need was to uncross the anterior bite, leading to a more favorable occlusal condition. The equipment selected was an SPDT (Special Planas Direct Tracks) functional orthopedic device with a progeny arch.

The initial and expected results were achieved within 40 days

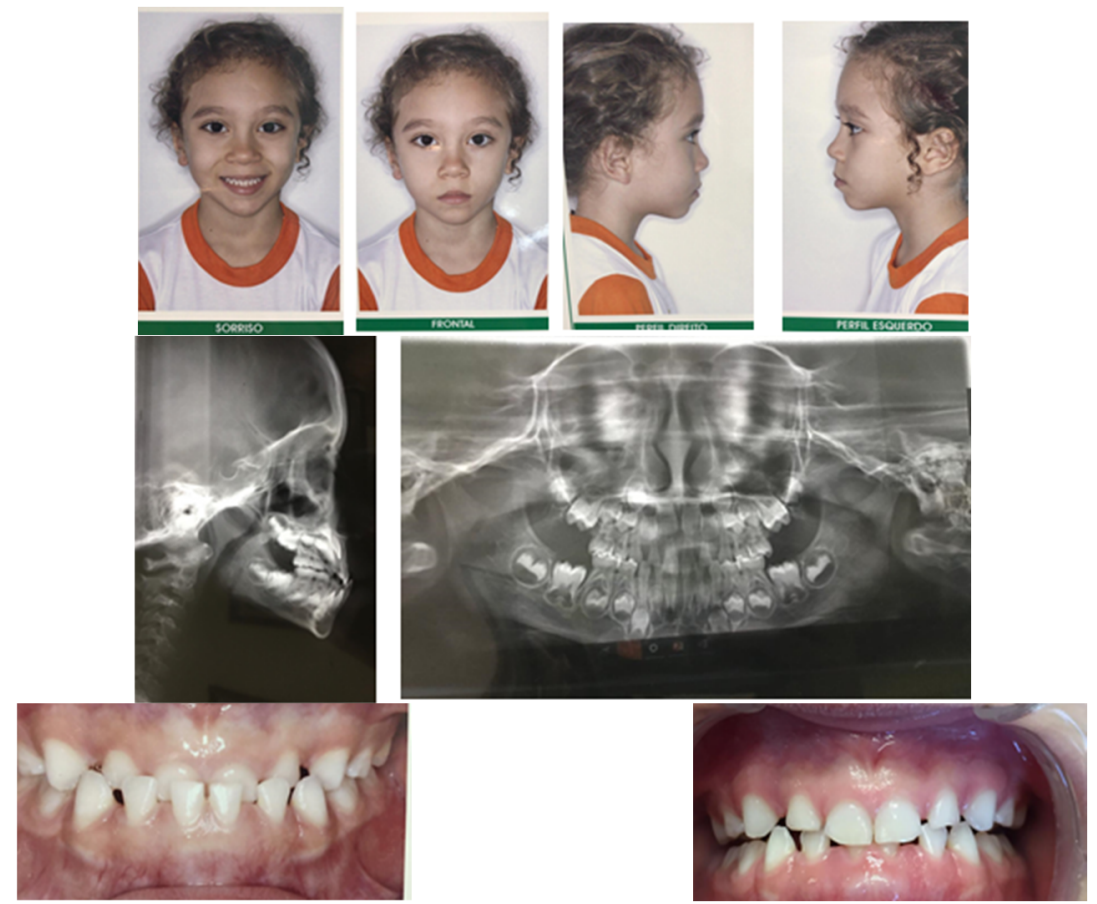

Fig. 3. Extra- and intraoral photographs (upper and lower section, respectively); Teleradiograph and panoramic radiography (second line)

\subsection{Case 3}

JCCC, three years old, male, mixed-race Brazilian ("parda").

Chief complaint: Difficulty in chewing.

History of current disease: No systemic changes, no history of trauma or idiopathic dysfunction.

Clinical examination showed complete deciduous dentition, harmonic profile, forced lip sealing, and functional mesiocclusion. Altered edging movements.

Proposed therapy: In the assessment of priorities, the previous uncrossing was offered by making direct tracks to teeth 51 and 62 with a light-cured composite resin. Physiological anterior overlap was achieved within 15 days of performing the tracks.

\subsection{Case 4}

MCS, four years old, female, mixed-race Brazilian ("parda").

Chief complaint: "crooked bite", difficulty chewing, and shame in smiling. 
History of the current disease: No reports of complications during childbirth, development, and sleep. Absence of harmful habits.

Family history: No cases of malocclusion in the family.

The functional examination showed physiological protrusive movement. Bilateral chewing, phonation, and swallowing without alterations. On the X-ray examination in the lateral view, an open gonial angle was observed, an acute notch, an increase in the lower anterior third of the face.

Proposed therapy: Functional orthopedic device type SN3 with progeny arch, used for one year. As its primary function, the chosen device has the mandibular rotation that induces a convenient lingual posture. After four months of using the device, the bite was uncrossed.
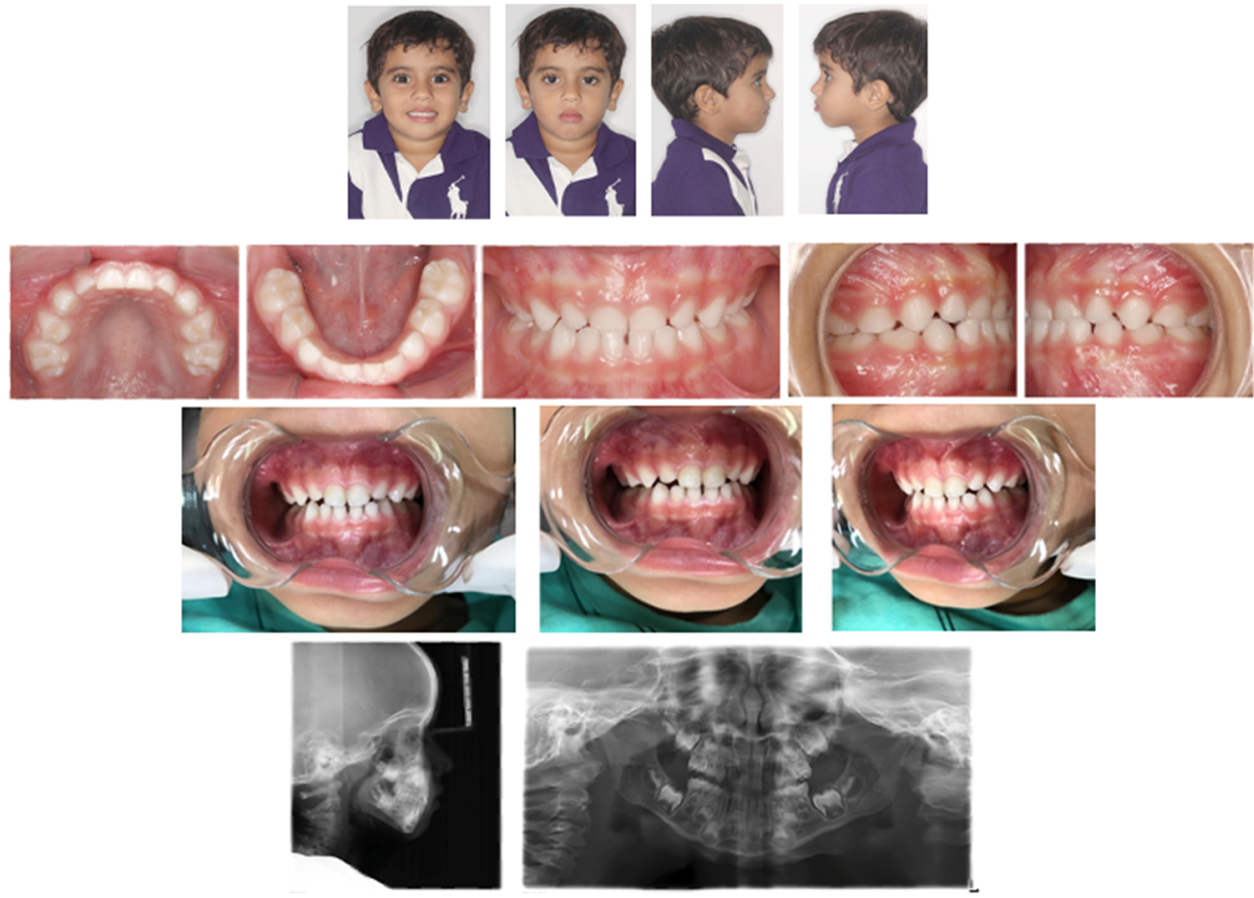

Fig. 4. First line: face photographs; Second and third line: intraoral photographs; fourth line: panoramic radiograph and teleradiograph
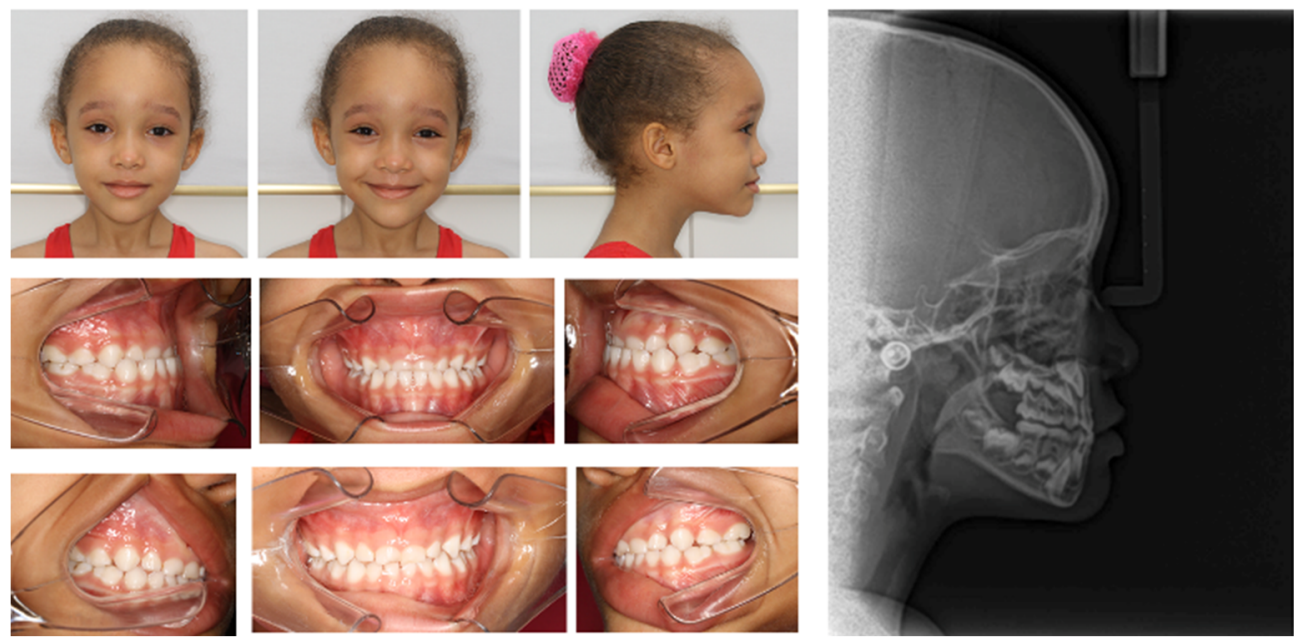

Fig. 5. Extra- and intraoral photographs; teleradiograph (on the right) 


\section{Discussion}

It has already been demonstrated that the early management of Class III malocclusions has a substantial influence on the short- and long-term outcomes. The main objectives of early intervention are to provide a more favorable condition for proper growth and improve the facial relationship, for example, to correct crossbite and facial aesthetics [10]. In addition to prevent changes in soft tissues or even bone tissue, to improve skeletal relationships, which in turn minimize excessive dental compensation, such as retroinclination of the lower incisors, which will enhance occlusal function since class III malocclusions with anterior crossbite are often accompanied by mandibular functional changes, simplifying the comprehensive treatment of class III, because in many cases, early orthodontic or orthopedic treatment can eliminate the need for future surgical treatment and even if surgery is eventually necessary can minimize the length of the surgical procedure [11], and finally, to provide a more pleasant facial esthetics, thus improving a child's psychosocial development [4].

In all the cases described, there is a new touch between the incisors, a new posture, and mandibular dynamics, respecting the principles of Jaw Functional Orthopedics.

Many authors agree that the need for early diagnosis and intervention is vital for a favorable prognosis, although long-term stability is related to favorable growth, in the treatment of class III malocclusion, doubts are related to the chosen therapy [1]-[4], [7], [10]-[12], [14]-[22].

Maxillary protraction is the treatment of choice in most cases, but it is necessary to look carefully at interventions in primary dentition and before the eruption of permanent molars, as these cases often evolve into orthognathic surgery and are treated at a timely age, and may prevent or even decrease the surgical supply [1]-[3].

This article aimed to show Jaw Functional Orthopedics' treatment options at the lower primary and secondary levels [10], [15].

In Jaw Functional Orthopedics, it is mandatory to unravel the anterior bite regardless of what type of mesiocclusion the patient presents. In addition, by correcting Class III malocclusion during primary dentition, a new occlusion will lead to the correct stimuli for the harmonic development of the facial maxillary complex [7]. According to the American Academy of Pediatric Dentistry, the presented clinical cases exemplify the benefits of the early treatment of mesiocclusion, offering the patients adequate incisive touch, which allows a harmonic occlusion relationship.

\section{Conclusions}

Jaw Functional Orthopedics is an option to correct mesiocclusion at an early age.

There is a need for high-quality clinical trials to identify effective interventions to treat previous anterior crossbites at a timely age.

\section{References}

[1] E. Zere, P. K. Chaudhari, J. Saran, K. Dhingra, and N. Tiwari, "Developing class III malocclusions: challenges and solutions," Clinical, Cosmetic and Investigational Dentistry, Vol. Volume 10, pp. 99116, Jun. 2018, https://doi.org/10.2147/ccide.s134303

[2] F. Borrie and D. Bearn, "Early correction of anterior crossbites: a systematic review," Journal of Orthodontics, Vol. 38, No. 3, pp. 175-184, Sep. 2011, https://doi.org/10.1179/14653121141443

[3] R. A. Minase, W. A. Bhad, and U. H. Doshi, "Effectiveness of reverse twin block with lip pads-RME and face mask with RME in the early treatment of class III malocclusion," Progress in Orthodontics, Vol. 20, No. 1, p. 14, Dec. 2019, https://doi.org/10.1186/s40510-019-0266-0

[4] P. Ngan, "Early timely treatment of class III malocclusion," Seminars in Orthodontics, Vol. 11, No. 3, pp. 140-145, Sep. 2005, https://doi.org/10.1053/j.sodo.2005.04.007

[5] M. S. Alhammadi, E. Halboub, M. S. Fayed, A. Labib, and C. El-Saaidi, "Global distribution of malocclusion traits: A systematic review," Dental Press Journal of Orthodontics, Vol. 23, No. 6, pp. 40.e1-40.e10, Dec. 2018, https://doi.org/10.1590/2177-6709.23.6.40.e1-10.onl

[6] W. Simões, Ortopedia Funcional dos Maxilares. 1th edt.. Ribeirão Preto: Editora Tota, 2013, p. 360. 
[7] American Academy of Pediatric Dentistry. "AAPD | Management of the Developing Dentition and Occlusion in Pediatric Dentistry. The Reference Manual of Pediatric Dentistry 2020-2021.". https://www.aapd.org/research/oral-health-policies--recommendations/management-of-thedeveloping-dentition-and-occlusion-in-pediatric-dentistry/ (accessed 2019).

[8] American Academy of Pediatric Dentistry, "Acquired temporomandibular disorders in infants, children, and adolescents. The Reference Manual of Pediatric Dentistry," Chicago, 2020.

[9] D. Turpin, "Turpin's positive and negative factors for decision making for interception of developing Class III malocclusion," in 81st Annual Session, American Association of Orthodontics, 1981.

[10] W. A. Simões, "Ortopedia funcional dos maxilares: através da reabilitação neuro-oclusal," Ortopedia funcional dos maxilares: através da reabilitação neuro-oclusal, pp. 534-534, 2003.

[11] M. Pereira, Manual de Ortopedia Funcional dos Maxilares: uma abordagem clínico - infantil. São Paulo: Editora Santos, 2017.

[12] P. Planas, Rehabilitación Neuro-Oclusal (RNO). Barcelona: Salvat Editores, 1987, p. 317.

[13] A. Petrovic, "Un enfoque cibernético de los mecanismos de contról del crescimiento craniofacial," in Aguilla FJ, Enlow DH, Crecimiento craneofacial. Ortodoncia y Ortopedia. 1 ed. Actualidades médico odontologicas latino américa, 1998.

[14] P. Valério, "A importância da ortopedia funcional dos maxilares como promotora do correto crescimento craniofacial," Rev. Assoc. Paul Cir. Dent, Vol. 73, No. 2, pp. 142-143, 2019.

[15] W. A. Simões, "Levels of prevention in orthodontics and their value to pedodontics," The Journal of Pedodontics, Vol. 5, No. 3, pp. 211-221, 1981.

[16] H. Sarangal, R. Namdev, S. Garg, N. Saini, and P. Singhal, "Treatment modalities for early management of class III skeletal malocclusion: a case series," Contemporary Clinical Dentistry, Vol. 11, No. 1, p. 91, 2020, https://doi.org/10.4103/ccd.ccd_393_19

[17] N. Mandall et al., "Early class III protraction facemask treatment reduces the need for orthognathic surgery: a multi-centre, two-arm parallel randomized, controlled trial," Journal of Orthodontics, Vol. 43, No. 3, pp. 164-175, Jul. 2016, https://doi.org/10.1080/14653125.2016.1201302

[18] J. Seehra, P. S. Fleming, N. Mandall, and A. T. Dibiase, "A comparison of two different techniques for early correction of class III malocclusion," The Angle Orthodontist, Vol. 82, No. 1, pp. 96-101, Jan. 2012, https://doi.org/10.2319/032011-197.1

[19] L. Perillo, M. Vitale, C. Masucci, F. D. 'Apuzzo, P. Cozza, and L. Franchi, "Comparisons of two protocols for the early treatment of Class III dentoskeletal disharmony," The European Journal of Orthodontics, Vol. 38, No. 1, pp. 51-56, Feb. 2016, https://doi.org/10.1093/ejo/cjv010

[20] J. H. Willmann, M. Nienkemper, N. E. Tarraf, B. Wilmes, and D. Drescher, "Early class III treatment with Hybrid-Hyrax - facemask in comparison to hybrid-hyrax-mentoplate - skeletal and dental outcomes," Progress in Orthodontics, Vol. 19, No. 1, p. 42, Dec. 2018, https://doi.org/10.1186/s40510-018-0239-8

[21] M. Begum Khan and A. Karra, "Early treatment of class III malocclusion: a boon or a burden?," International Journal of Clinical Pediatric Dentistry, Vol. 7, No. 2, pp. 130-136, Aug. 2014, https://doi.org/10.5005/jp-journals-10005-1250

[22] K. Khalaf and M. Mando, "Removable appliances to correct anterior crossbites in the mixed dentition: a systematic review," Acta Odontologica Scandinavica, Vol. 78, No. 2, pp. 118-125, Feb. 2020, https://doi.org/10.1080/00016357.2019.1657178

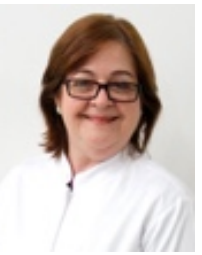

Maria Rita Xavier Sancho Rios is a Specialist in Orthodontics (Bahia Federal University, Brazil, 1996) and Specialist in Functional Jaw Orthopedics (CFO, Brazil, 2002). She received a master's degree in Health Science (São Paulo University, Brazil, 2006). Currently works in the specialty line. Your current diagnostic research interests in early treatment and TMJ. 


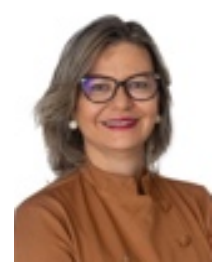

Andrea Alves de Carvalho received a Master's degree in Interactive Organ and System Processes (Federal University of Bahia, Brazil). Additionally, she is a Specialist in Pediatric Dentistry (Federal University of São Paulo, Brazil) and Dentistry for handicap patients (CFO, Brazil). She is currently enrolled in the doctorate program in Interactive Process of the Organs and Systems (Federal University of Bahia, Brazil).

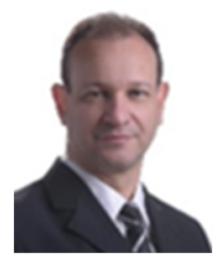

Adrião Silveira Martins is a Specialist in Jaw Functional Orthopedics (ABO, Bahia, Brazil, 2000) and in Orthodontics (ABO, Bahia, Brazil, 1994). Currently, he is a Professor of the Specialization course in Jaw Functional Orthopedics and Orthodontics (ABO, Bahia, Brazil)

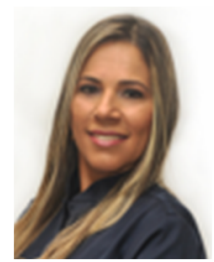

Anne Souza Nery is a Specialist in Functional Jaw Orthopedics (ABO, Bahia, Brazil, 2008). Her currently work in my area. Currently works in the specialty line. Your current diagnostic research interests in computerized imaging.

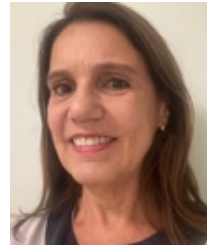

Maria Amélia Drummond is a Specialist in Jaw Functional Orthopedics (ABO, Bahia, Brazil, 2000) and Pediatric Dentistry. Currently works in the specialty line. 